\title{
Urinary tract infection associated with indwelling catheters in a intensive care unit: a preventive approach
}

\author{
MR Silva ${ }^{1,2^{*}}$, MDCF Araujo ${ }^{1}$, THRC Almeida ${ }^{3}$, EC Santos $^{4}$, T Figueiredo $^{4}$, DA Barbosa ${ }^{2}$ \\ From ESICM LIVES 2015 \\ Berlin, Germany. 3-7 October 2015
}

\section{Introduction}

Urinary tract infection when associated with bladder catheterization delay is one of the most common causes of infection related to health care, accounting for $40 \%$ of the incidence. Much of microorganisms that contaminate the drainage system stems from inadequate aseptic technique and hygiene oversights in the microbiota of the perineal and perianal region. It is an infection with high preventive potential, suggesting the need for educational interventions, with the purpose to train professionals, aimed at prevention and health promotion.

\section{Objective}

To evaluate the incidence after educational intervention on bladder catheterization delay on the insertion technique and maintenance care, the nursing staff.

\section{Methodology}

Descriptive, exploratory, quantitative study in a hospital in the southern region of Bahia-Brazil. Data collection was conducted from March to November 2014. The study population were 50 patients admitted to the intensive care unit. The Ethics Committee protocol and the Federal University of São Paulo: 319 255/2013.

\section{Results}

Prevalence of infections in male patients: 35 (70\%). Diagnostic: Encephalopathy 16 (32\%). Age group: 6887 years old: 23 (46\%). Length of stay: 1 to 17 days: 43 (86\%). Type catheter material Foley and Latex: 50 (100\%). Catheter dwell time: 6 to 10 days: 23 (46\%).

${ }^{1}$ Universidade Estadual de Santa Cruz, Health Sciences, Ilhéus, Brazil Full list of author information is available at the end of the article
Laboratory tests confirmed: 12 (24\%), and the Escherichia coli frequently identified microorganism. No infection: 38 (76\%). The indicators assessed as adequate in $100 \%$ : indication of the catheter, closed drainage system maintenance, positioning the collection bag, clear urine flow. In 32 (64\%): Fixing the catheter, still requires greater vigilance.

\section{Conclusion}

After training and constant supervision of professionals and adherence to measures to prevent and control the catheter, it was possible to identify the profile of the unit and realize a reduction in the incidence of urinary tract infection.

\section{Grant Acknowledgment}

Follow the recommendations of best practices to provide direct patient care, the teacher serves as a model and operates in favor of its security, the teams and patients. Pay attention to the infection indicators is quality of care provided to patients.

\section{Authors' details \\ ${ }^{1}$ Universidade Estadual de Santa Cruz, Health Sciences, Ilhéus, Brazil. ${ }^{2}$ Universidade Federal de São Paulo, Health Sciences, São Paulo, Brazil. ${ }^{3}$ Universidade Estadual de Santa Cruz, Health Sciences, Ilheus, Brazil. ${ }^{4}$ Base Hospital Luis Eduardo Magalhães, Nursing, Itabuna, Brazil.}

Published: 1 October 2015

\section{References}

1. National Health Surveillance Agency: Series Patient Safety and Quality in Health Care Notebook 2. Related Infection Diagnostic Criteria for Health Care 2013.

2. Fernandes MVL, Lacerda RA, Hallage NM: Development and validation of indicators for evaluating control practices and prevention of catheterassociated urinary tract infection. Acta Paul Enferm 2006, 19(2):174-89.

\section{SpringerOpen ${ }^{\odot}$}

(C) 2015 Silva et al.; This is an Open Access article distributed under the terms of the Creative Commons Attribution License (http:// creativecommons.org/licenses/by/4.0), which permits unrestricted use, distribution, and reproduction in any medium, provided the original work is properly cited. 
3. Centers for Disease Control and Prevention: Healthcare Infection Control Practices Advisory Committee. Guideline for Prevention of Catheter Associated Urinary Tract Infections 2009.

doi:10.1186/2197-425X-3-S1-A1019

Cite this article as: Silva et al:: Urinary tract infection associated with indwelling catheters in a intensive care unit: a preventive approach. Intensive Care Medicine Experimental 2015 3(Suppl 1):A1019.

\section{Submit your manuscript to a SpringerOpen ${ }^{\mathcal{O}}$ journal and benefit from:}

- Convenient online submission

- Rigorous peer review

- Immediate publication on acceptance

- Open access: articles freely available online

- High visibility within the field

- Retaining the copyright to your article

Submit your next manuscript at $\gg$ springeropen.com 